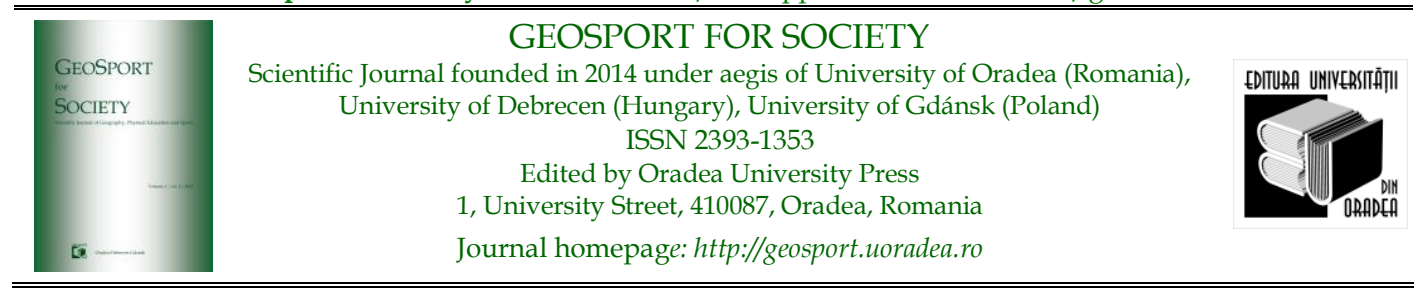

\title{
The Urban Legacy Impacts of Mega-Event Stadia: Selected Case Studies from South Africa
}

\author{
Hilary K. N. BAMA ${ }^{1 *}$, Tembi M. TICHAAWA ${ }^{1}$ \\ 1. University of Johannesburg, School of Tourism and Hospitality, College of Business and Economics, Bunting Rd, \\ Cottesloe, 2092, Johannesburg, South Africa, e-mails: tembit@uj.ac.za, hbamason@gmail.com \\ * Corresponding author
}

Citation: Bama, H.K.N. , Tichaawa, T.M. (2021). The Urban Legacy Impacts of Mega-Event Stadia: Selected Case Studies from South Africa. Geosport for Society, 14(1), 28-46. https://doi.org/10.30892/gss.1404-074

Article history: 21.05.2021; Revised: 30.05.2021; Accepted: 01.06.2021, Available online: 02.06.2021

\begin{abstract}
This study considered the urban infrastructure legacy impacts of mega-events in the Global South with a specific focus on South Africa's 2010 stadia. By way of multiple case studies, undertaken in 2010 FIFA World Cup stadia in host cities Cape Town, Durban and Port Elizabeth, and applying a mixed-method approach, $\mathrm{n}=1120$ urban residents living within a $2-\mathrm{km}$ radius were surveyed in addition to interviews with key resource persons. The empirical findings indicate the existence of significant statistical differences in the perceptions of the urban residents and other stakeholder groups regarding the sustainability precepts that accompany the construction of stadia associated with the long-term urban infrastructure legacy implications. While the urban residents and the key resource persons agreed that the stadia had the potential to attract positive urban infrastructure legacy outcomes to their communities, one of the critical observations noted was the agreement that the costs associated with the maintenance and operations of these stadia were currently enormous, posing significant sustainability challenges and contentions. The study provides fresh insights into long-term mega-event urban infrastructure legacy impact assessment from a developing country perspective with innovative planning and strategy implications.
\end{abstract}

Keywords: Mega-event stadia, FIFA World Cup, tourism, sustainability, infrastructure development, legacy

\section{Introduction}

This study considered the urban infrastructure legacy impacts of mega-events in the Global South with a specific focus on South Africa's 2010 stadia. Mega-events have featured prominently on the agendas of countries of the Global South in the last few decades and contemporary discourse indicates robust engagements by these countries in the mega-event complex with prime intention to leverage their catalytic infrastructure development impetus while being increasingly incorporated into their urban planning agendas (Hemmonsbey and Tichaawa, 2018, 2019; Koch and 
Valiyev, 2016; Preuss, 2015; Wood, 2017; Stewart and Rayner, 2016; Chen et al., 2013; Steinbrink et al., 2011; Kassens-Noor and Kayal, 2016). There has therefore been an increased significance in mega-events due to their potential to transform entire urban spaces (Preuss, 2015; Philips and Barnes, 2015; Kassens-Noor and Kayal, 2016). In 2010, South Africa hosted the first ever FIFA World Cup to be held on the continent since the inception of the showpiece (Tichaawa and Bama, 2012; Swart and Bob, 2012). In preparations for the hosting of the event, local authorities, urban planning and other event proponents suggested that the hosting of the event stood the chance of fast-tracking developmental projects, often related to stadia, housing, transport and telecommunications, and by implication, that it similarly would transform the image of the cityscape with the resultant effect of attracting increased tourism (Hemmonsbey and Tichaawa, 2018, 2019; Ilieș et al., 2014. Kassens-Noor and Kayal, 2016; Stewart and Rayner, 2016; Chen et al., 2013; Kunzmann, 2016; Steinbrink et al., 2011). Specifically, in the case of stadia, contentions were that enormous resources, both financial and physical, would be committed to ensuring their readiness for the events, an assertion which was true for the case of the 2010 FIFA World Cup hosted by South Africa. In this regard, Bama (2018) notes that South Africa spent in the region of R17 billion in the construction and upgrading of stadia alone, a figure which Molloy and Chetty (2015) highlighted constituted the largest portion of the budget outlay for the entire 2010 FIFA World Cup event preparations.

In mega-event legacy discourse, few studies have looked at the infrastructure legacy constructs that often accompany the hosting of these events as well as the post-event sustainability of these structures. As such, the knowledge regarding legacy planning, delivery, and the barriers associated with realising legacies is fragmented which raises the issue of the need for a holistic approach towards understanding how legacy is delivered (Bocarro et al., 2018; Hemmonsbey and Tichaawa, 2018, 2019; Thomson et al., 2018). Specifically, in the developing context, and owing to the fact that between 2010 and 2022, all mega-events in this category (Olympic Games or FIFA World Cup) have been hosted in emerging destinations, with Africa (FIFA World Cup South Africa 2010), Eastern Europe (FIFA World Cup Russia 2018), the Middle East (FIFA World Cup Qatar 2022), and the first Olympic Games in South America (Rio de Janeiro 2016), integrated strategies are needed in order to maximise the legacy outcomes of such events. The only exception within this period is the upcoming Olympic Games that were granted to Tokyo, Japan to be held in 2021 (Müller and Gaffney, 2018). This apparent dominance by emerging economies in the mega-event complex begs for a concise consideration of their legacy outcomes, specifically around stadium infrastructure legacies, which often form spatial and architectural markers for the host destinations in the aftermath of the events. By adopting selected stadia across South Africa that were constructed for the hosting of the 2010 FIFA World Cup, this paper considers stakeholder views in relation to the debates surrounding the legacy impacts of mega-event stadia in the context of the Global South while paying attention to issues around their sustainability. Furthermore, there seems to be mounting evidence which challenges the ability of mega sport events to produce sustainable, positive legacies, prompting 
further research on whether legacy is indeed mutable in the context of stadium infrastructure development (Bama, 2018; Brittain et al., 2018). Following calls for mega-event legacy impact research to be conducted over time; this study considers the urban infrastructure legacy dimensions with specific reference to those linked to stadia. In pursuing this objective, the study is structured in the following manner: the literature review puts mega-event legacy in context for the study concerned, while it discusses key concepts around legacy in terms of sustainability within a developing context. The study's mixed (quantitative and qualitative) methodological framework is highlighted in the subsequent section, and, thereafter, a descriptive and thematic presentation of the study's findings is elaborated upon and discussed, based on indepth analysis of the data. Lastly, the study's implications are outlined, before the study concludes with final remarks and recommendations for future research.

\section{Literature Review}

\section{Mega-event legacy in the context of stadium infrastructure}

Mega-events are a feature of modern urban life and are an integral component of 20th-century urban development. Kim et al., (2019) and Kassens-Noor et al., (2019) assert that mega-events have been shown to affect the environments within which they are hosted with various transformative changes including the opportunity to develop tourism-related infrastructure and media attention. Clark et al., (2016), highlight that in many ways the essence of mega-events is linked to scale. Increasingly, such events are being hosted by countries in the 'Global South', raising new challenges as to how they are organised, and what impacts they might portend (Byers et al., 2019; Robbins, 2012). These mega-events have often been justified as catalytic in terms of their ability to engender urban transformation and other legacy benefits (Hemmonsbey and Tichaawa, 2018, 2019; Kim et al., 2019; Müller and Gaffney, 2018). According to Philips and Barnes (2015), the planning of urban development in the developing context involves making the urban landscape more livable by addressing challenges around urban poverty, inequality and environmental decay, and as such, urban planners tend to rely on leveraging megaevents as urban planning strategies for their development related impacts, a position which is acknowledged by other scholars in the area (Bama and Tichaawa, 2020; Byers et al., 2019; Ferrari and Guala, 2017; Steinbrink et al., 2011). In addition, urban planners and event proponents have been noted to use the hosting of mega-events along four integral dimensions, in relation to which scale should be considered: visitor attractiveness; mediated reach; cost, and transformative impact (Hemmonsbey and Tichaawa, 2018, 2019; Müller, 2017).

In the process of the hosting of these mega-events, there is a need for investments to be made in the area of infrastructure that will be used for the event (Byers et al., 2019; Groothuis and Rotthoff, 2014). According to Cottle (2010), such investments often attract a high premium to the host community which, as opined by Müller and Gaffney (2018), include capital cost of material interventions in the city such as the upgrading or building of new sports venues, roads, railway lines, airports, conference centres, security systems, and hotels and often runs into billions of dollars, which is several times the operational cost of putting on the event 
itself (Humphrey and Fraser, 2016; Gold and Gold, 2016). The escalating costs, and the increasingly substantial sums of taxpayers' resources that are regularly sunk into preparing the stadia for such hosting activities, often are followed by either low keyed legacy outcomes with little or scant policy learning taking place (Bama and Tichaawa, 2020; Girginov, 2011; Grix and Brannagan, 2017; Kim et al., 2019; Leopkey and Parent, 2012; Tomlinson, 2014). Legacy should, therefore, be considered as a high-risk strategy for justifying exorbitant expenditures on sport mega-events with no dedicated focus on research that informs the existence and process through which sport mega-events enhance the attainment of legacies (Byers et al., 2019; Zimbalist, 2017). Extant literature related to sport event legacies suggest that legacy planning should be adopted at the inception stage of the conceptualisation of the events and that an impacts and implementations team be constituted and adequately funded after the event in order to ensure that the legacy plan is executed and monitored in the events' aftermath - especially legacy considerations around infrastructure linked to stadia (Bama and Tichaawa, 2020).

According to Black (2007) and Philips and Barnes (2015), the pursuit of sport mega-events by the developed and the developing countries is linked to the exigencies and the impetus of mega-events acting as developmental strategies. Mega-event boosters have often provided positive projections of their intentions towards the hosting of mega-events. According to Gaffney (2013), the preparations for the hosting of the flagship events are often preceded by massive investments in infrastructure, both in terms of the event-related infrastructure, such as the stadia, and other related infrastructure investments, such as transport infrastructure upgrades, roads, airports and others. Infrastructural development and sustainability contestations are, therefore, gaining prominence among participants seeking to deliver sustainable mega-events (Humphrey and Fraser, 2016; Preuss, 2015; Tichaawa et al., 2015). To this end, opponents have variously indicated that such infrastructure investments sometimes come with huge financial burdens. For example, Hlabane (2012:102) highlights figures presented by Sturgess and Brady (2006:28), who indicate that, for the FIFA World Cup event co-hosted by Japan and Korea in 2002, "a combined sum of US\$ 4.5 billion was spent on stadia alone". In the case of Germany, a total of US $\$ 1.92$ billion was invested in developing stadia for the 2006 FIFA World Cup (Sturgess and Brady, 2006). The authors further opined that the trend is suggestive of the fact that the sums allocated for building stadia have been increasing, and that the numbers are expected only to rise further in the future (Sturgess and Brady, 2006). Additionally, a plethora of studies have indicated that the impacts of sport stadia to local economies have not been in alignment with related theory (Alm et al., 2012; Byers et al., 2019; Groothuis and Rotthoff, 2014; KassensNoor et al., 2019; Kim et al., 2019). To situate the discussion and debates in context, the urban nature of these mega-event stadia receive some consideration next.

\section{The urban nature of the mega-event stadia}

The allure of sport mega-events has been noted as a means by which hitherto dilapidated urban areas can be re-energised and renewed (Coates, 2007; Gaffney, $2013,2015)$. Undoubtedly, stadia impact on their locality and on the larger urban 
environment (Gaffney, 2013). Mega-events are considered as urban spectacles for the most part, with investing in them consequently affecting the urban spaces within which they occur (Blomgren and Valkonen, 2007; Coates, 2007; Gaffney, 2013, 2015; Jaworek et al., 2020; Montgomery, 2008; Moshoeshoe, 2014). According to Rosentraub (2010), the construction of a stadium in a downtown area has been shown to be capable of positively revitalising such an area by encouraging far greater private development in the surrounding areas. The successfulness of stadia has mostly been rated in terms of their ability to spur on economic development in their surrounding areas (Koehler, 2012). A key element in urban discourse that could largely affect the success of sports stadia is their location, with Koehler (2012), in such regard, stating that the only stadia that have successfully revitalised their surrounding areas have been those that are situated in the downtown areas of cities. An argument that was put forward for the construction of the stadium in Cape Town in the run-up to the 2010 FIFA World Cup was that the stadium would help with the urban regeneration of the city, and specifically the Athlone area, where the stadium was initially meant to have been located (Swart and Bob, 2009).

Furthermore, other urban-demography-related characteristics that have been noted to encourage successful stadia relate to the sizes of the stadia, to the distance of the stadia from public transport, and to other socio-demographic indicators, such as the average income and crime statistics in the surrounding areas (Coates, 2007; Koehler, 2012; Mills and Rosentraub, 2013; Rosentraub, 2010). Such outcomes have, however, only been successfully tested in the Global North, and the context and outcomes might be very different in the case of the Global South economies that have, in the recent past, also been involved in the mega-event complex. Examples abound of where the residents have tended to resist the attending of events in the stadia, even though the stadia are situated well within the inner limits of cities, with urban transport networks available, and with almost negligible crime rates (Grix and Brannagan, 2017; Moshoeshoe, 2014; Swart and Bob, 2012). In the case of the 2014 FIFA World Cup and the 2016 Summer Olympics having been hosted by Brazil, the indications have shown that the infrastructure-related investments that were made in the run-up to the events assumed an 'unsustainable status' that was similar to the claims that have been levied on the stadia in South Africa since the end of the 2010 FIFA World Cup (Douglas, 2015; Gaffney, 2015; Kiernan, 2014; Patel, 2016). Thus, stadium-related legacies have become contentious mega-event legacy narratives, owing to their costs relative to their benefits.

\section{Legacy impacts of mega-event stadia within the developing context}

Among the multitude of studies that have focused on examining the concept of legacy, the majority concur that mega-event legacies are the outcomes that could be linked not only to the permanent sequel, but also to the adaptations to, changes or readjustments to normality as a function of the outcomes of the event (Bama and Tichaawa, 2015; 2016; Black, 2007; Cashman and Horne, 2013; Chappelet and Junod, 2006; Cornelissen, 2007; Cornelissen et al., 2011; Hemmonsbey and Tichaawa, 2019; Preuss, 2007, 2011, 2013; Smith and Fox, 2007). Mega-event hosting necessitates the investment into the creation of infrastructure such as stadia 
(Groothuis and Rotthoff, 2014). These stadia investments usually come at a high premium to the host community (Cottle, 2010; Molloy and Chetty, 2015). Certain factors have rendered the study of the nature of the events more relevant in contemporary times. The factors consist, among others, of the increasingly wide range of states seeking to host them, including those from the Global South, the escalating costs, and the increasingly substantial sums of taxpayers' resources that are regularly sunk into preparing the stadia for such hosting activities. In addition, such factors include the justificatory discourse around the spending on such events, whereby the stadium infrastructure legacies are brandished as the key return on investment. Despite the mounting evidence that many of the stadium-linked legacies have failed to materialise, the perennial sport event cycle has continued, with little policy learning taking place (Girginov, 2011; Grix and Brannagan, 2017; Leopkey and Parent, 2012; Tomlinson, 2014).

However, it has also been noted, variously, that the provision of such sport infrastructure such as stadia, beyond being used for the sporting competition, also portends an array of positive and negative legacy impacts on the host communities of mega-events. For example, mega-sporting events are considered capable of generating positive outcomes and consequences for the host communities, such as image enhancement, urban regeneration and renewal, heightened awareness, leisure resource development, positive socio-economic impacts, and infrastructure development. In contrast, the negative impacts for the host community could include, for example, the high costs for stadium construction, negative socioeconomic impacts, traffic problems, increases in the cost of living, gentrification, overcrowding, and societal and cultural problems (Almeida et al., 2014; Girginov, 2011; Grix and Brannagan, 2017; Leopkey and Parent, 2012).

The hosting of the 2010 FIFA World Cup in South Africa was the first of the first-order mega-events to be staged on African soil within the context of the developing economies. Cezne (2014), therefore, highlights the contention that, historically, mega-events have managed to transmit powerful messages, playing a multitude of both explicit and implicit roles. The heightened consideration of such potential is encapsulated by Erten and Özfiliz (2006:525) in their analysis and commentary in relation to the potential of mega-event stadia when they state that "[S]tadia have always been significant urban elements for many reasons like the extent of the area that they occupy in a city, their size, their function, the spatial relations they motivate." Cornelissen et al. (2011) contend that the development of stadia in the mega-event literature is pursued based on the critical component of the legacies that are associated with the hosting of such mega-events. In the case of South Africa and the hosting of the 2010 FIFA World Cup, a plethora of researchers postulate that the stadia were extremely costly to build, with costs rising from the initial estimates of R2.5 billion to R8.4 billion, and then, finally, to over R10 billion by the time of their completion (Desai and Vahed, 2010; Jory and Boojihawon, 2011; Maharaj, 2011; Tichaawa and Bama, 2012). The final figures, according to Hlabane (2012), suggest that the stadium construction and upgrades programme for the 2010 FIFA World Cup cost the South African government R16.16 billion. 
In the current era of global urbanism, the intricate relationship between capital accumulation and urban spatial transformation in the context of megaevents, often engendered through event-driven strategies remain contested and uncertain (Lin and $\mathrm{Xu}, 2019$ ). Specifically, impact-related and legacy debates and discourses relating to the stadia that are often constructed for such events are scant. Ren (2017) intimates that most existing enquiry does not venture enough into the complex layers of institutional contexts that underpin the structure of event-driven urbanisation and its outcomes. Meanwhile, Lin and Xu (2019) assert that extant literature on mega-events provides contentious and competing interpretations of such strategy. It is hoped therefore that the current study delves into these conundrums and provides fresh insight into how these stadium-related infrastructure legacies could be comprehensively identified by future host communities, especially within the developing context.

\section{Methodology}

In examining the perceptions of urban residents in relation to mega-event stadia development and their urban legacy implications, the study adopted a mixed method approach, applying both quantitative and qualitative techniques for the collection, analysis and the interpretation. The combination of these approaches has engendered the implementation of the pragmatic approach, especially adopted as it is regarded as the philosophic partner of mixed methods research and provides a workable solution to multifaceted research problems in relation to post-positivism (Johnson and Onwuegbuzie, 2004). The study was based on the Cape Town Stadium located in Cape Town, the Moses Mabhida Stadium located in Durban and the Nelson Mandela Bay Stadium located in Port Elizabeth. Figure 1 presents an illustration of the geographic representations of all nine host cities of the 2010 FIFA World Cup, also noting the case study areas under investigation. The justification for choosing the three stadiums was based upon the premise that each is primely located in the urban coastline of South Africa, with communities living close to them. Moreover, these stadiums were newly constructed for the purpose of the event and drew sharp criticism in terms of their choice of location (Swart and Bob, 2009).

The study targeted urban residents, living within a $2-\mathrm{km}$ radius of the three case study areas. This radius is recommended by previous relevant research that has found that such residents are more likely to be impacted by the stadium or hold a strong interest in them (Bassa and Jaggernath, 2010; Swart and Bob, 2009; Tichaawa and Bama, 2012). A total of 1120 (Cape Town $n=400$, Durban $n=320$, Port Elizabeth $\mathrm{n}=400$ ) willing adult members were randomly interviewed. The survey instrument that was used comprised of several questions linked to the sociodemographic profiles of the respondents. In addition, a traditional 5 point Likert type scale where $1=$ Strongly agree; to $5=$ Strongly disagree was used to rate several urban infrastructure related impact based statements that were informed by previous mega-event related studies (see for example Agha, 2013; Allen et al., 2013; Alm et al., 2012; Bob and Kassens-Noor, 2012; Cottle, 2010; Giampiccoli et al., 2015; Gunter, 2014) albeit they were modified to suit the current study objectives. The surveys were undertaken in 2016/17 (about 7 year's post-event) 
with the assistance of trained fieldworkers. Consequently, the surveys provide a long-term perspective of the resident' views on the stadia and urban infrastructure related legacy.

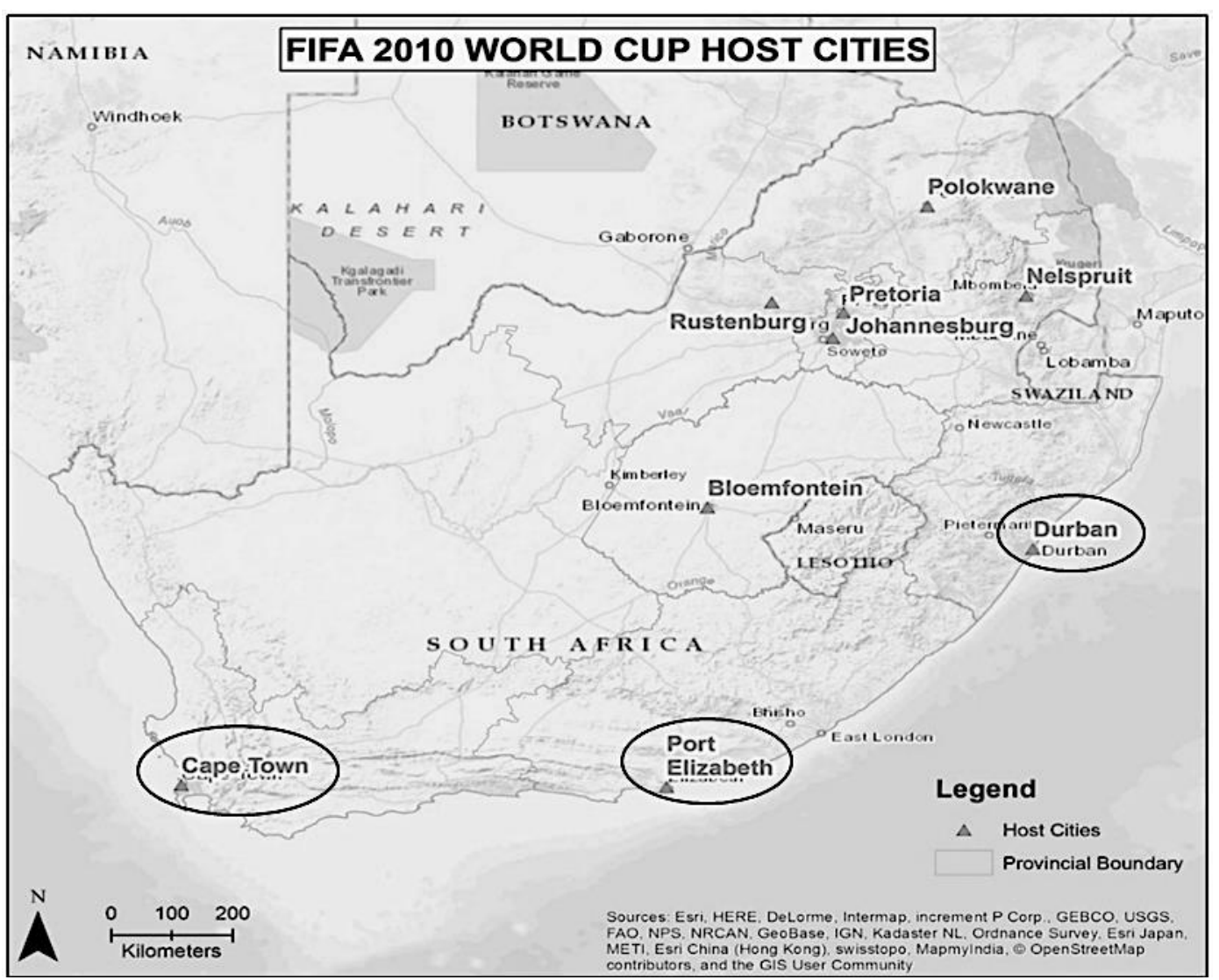

Figure 1. Geographic location of the 2010 FIFA World Cup host cities and case study areas (Source: Authors' based on fieldwork)

In addition to the surveys, the qualitative thrust included the administration of interviews to eight key resource persons including stadium management officials, municipal authorities who are directly linked to the management of the stadia and residents' associations' representatives in order to elicit their in-depth views on aspects related to the current study. The findings as collated will be elaborated upon both in terms of the descriptive presentations and thematic annotations. Discussions will accompany these presentations looking at the potential implications of the responses collated

\section{Results and Discussions}

\section{Demographic profiles of respondents}

The findings of the study established that the majority of the respondents across all three case study areas were male and mostly young professionals. The 
demographics further highlighted the cosmopolitan nature of urban populations within developing regions while also establishing their attitudes towards sport consumerism. Though these socio-demographic profiles quite evidently are linked generally to the attitudes of urban residents in terms of their propensity to participate in sport-related discourse and activities, they, however, are specifically based on the sample selection of the respective case study areas as opposed to general sport consumption patterns. The composition of urban residents within the social demography of the study would suggest a young, vibrant, energetic population. Middle-class professionals who earned enough to have disposable leisure time would also be in the category. Such profiles also bode well for a segment with more vested interests in the community, thereby making them more opinionated about the social phenomena within their communities. In the context of the current study, such a concentration of citizens within the urban space, especially within suburbs traditionally considered as upper-middle-class income suburbs, such as Green Point, one would imagine should augur well for their urban infrastructure and tourism consumption and therefore promote sustainable legacy implications of the respective stadia.

Table 1. Summary of sample profile of the respondents $(n=1120)$

\begin{tabular}{ll}
\hline Demographic variable & Percentage \\
\hline Age & 19.1 \\
18 - 20 years & 37.1 \\
21 - 30 years & 22.2 \\
31 - 40 years & 21.6 \\
40 years and older & \\
\hline Gender & 57.3 \\
Male & 42.7 \\
Female & \\
\hline Highest level of education & 2.4 \\
No formal education & 1.2 \\
Primary schooling completed & 5.3 \\
Secondary school completed & 23 \\
High school completed & 28.9 \\
Certificate/diploma & 24.2 \\
Undergraduate & 14.8 \\
Postgraduate & 0.2 \\
Other & \\
\hline Employment status & 10.3 \\
Unemployed & 18.4 \\
Student/ scholar & 2.3 \\
Retired & 10.7 \\
Unskilled labour & 45.6 \\
Skilled labour & 8.9 \\
Self- employed & 1 \\
Home executive & 2.8 \\
Other & In ZAR \\
\hline Highest monthly household salary range & $30000-40000$ \\
CPT & $20000-30000$ \\
DUB & $20000-30000$ \\
PE & \\
\hline ZAR refers to South African Rand 1 USD =13.74 ZAR (31/5/2021). & \\
\hline
\end{tabular}

ZAR refers to South African Rand; 1 USD = 13.74 ZAR (31/5/2021). 


\section{Infrastructure legacy dimensions linked to stadium construction}

Using ten different infrastructure related legacy variables, the current study set out to investigate and holistically present the infrastructure legacy outcomes linked to the construction of stadia for the 2010 FIFA World Cup. According to the results received, stakeholders were consistently positive in relation to the potential tourism benefits with most respondents $(76.9 \%$ from Cape Town, $76.3 \%$ from Durban and 61.4\% from Port Elizabeth) reporting that the presence of the stadium in their respective localities had increased the number of tourists coming into the area (V1). Cape Town emerged as the area with the most positive inclination to the statement, with $\mathrm{M}=3.97$ and $\mathrm{SD}=0.995$, followed by Durban, with $\mathrm{M}=3.84$ and SD $=0.825$, and Port Elizabeth, with $\mathrm{M}=3.64$ and $\mathrm{SD}=1.092$. Overall, the respondents across all three study areas expressed positive views with regards to the statement, recording a combined $\mathrm{M}=3.819$ and $\mathrm{SD}=0.997$ (Table 3). Similarly, there were generally well-held perceptions of media coverage of the area $(75.4 \%$ from Cape Town, 76.6\% from Durban and 62.3\% from Port Elizabeth) from respondents as a consequence of the presence of the stadia (V2). In concurrence, one of the key resource persons linked to the Cape Town Stadium noted that; "People keep on thinking about the stadium and events not happening in the stadium... if you have Lionel Ritchie, Linkin Park or Lady Gaga (performing here), you have people flying in from all over the world and they don't (only) come for the concert. They arrive three days before the concert, do the concert and then stay on for the rest of the week and then fly out. The economic spin-off for the city runs into millions and millions of Rands... So, while people may keep highlighting that the stadium is making an operational loss, it takes one concert (at the stadium) to push forty million Rands worth of direct spend into the city." While the Durban respondents reported slightly higher positive attitudes, with $\mathrm{M}=3.86$ and $\mathrm{SD}=0.676$, than did Cape Town, with $M=3.8$ and $S D=0905$, Port Elizabeth reported the least positive attitudes, with $\mathrm{M}=3.61$ and $\mathrm{SD}=1.091$. Again, the overall perceptions of the respondents were quite positive, with $\mathrm{M}=3.772$ and $\mathrm{SD}=0.930$ (Table 3 ).

With regards to the novelty status and tourism potential of these stadia, one of the key resource persons, a stadium management official from the City of Cape Town postulated that: "The amount of advertising the city got out of the Rugby Sevens tournament, for example, is simply phenomenal, and makes the stadium a powerful tool for positioning the city as a preferred tourism and events destination." In addition, the triangulated responses reported in relation to the novelty status of the stadia mostly highlighted that the stadia represented within the urban landscape, an aura and reminder of the tall order achieved by the hosting of the 2010 FIFA World Cup. These enlisted views were further encapsulated in the words of a key informant who contributed the following: "...and so our strategy is [i.e. has] been to try and keep it (the stadium) rather, and also that it is something a bit special; you know, it's not something that just anyone can go and use, it's kept for something special."

Furthermore, the study's results also noted that most of the respondents (79.7\% from Cape Town, 76.5\% from Durban and 63.3\% from Port Elizabeth) expressed pride for the construction of the stadium in their respective areas (V3). Overall, the respondents displayed positive perceptions across all three study areas, 
with a combined $\mathrm{M}=3.857$ and $\mathrm{SD}=0.995$, hinting at potential future support from the residents, who, over time, might have developed an affinity towards the stadia as a result of their novelty effects. In a nuanced twist though, one of the key resource persons noted that the invisible hand of FIFA played a key role in the determination of the location of the Cape Town stadium in Green Point, which even though a novel artefact, makes it difficult for the city to leverage on its urban renewal and regeneration efforts. Respondents $79.7 \%$ from Cape Town, 70.2\% from Durban and $62.9 \%$ from Port Elizabeth) further indicated that they remained enthusiastic and optimistic about the ability of the stadia to be used to develop football in the country, with most of the stadia also having the capacity to host multi-purpose activities (V4). While soccer remains a major sporting code in South Africa, attendance at the majority of PSL games has been minimal, as most fans prefer to watch games on TV, which begs the question of promoters having propounded that these stadia were intended to promote participation and also redress the backlog in sport infrastructure. Quizzed on how the stadia could engender sustainability, one of the key resource persons (an official from the City of Cape Town), in referring to the potential move of the local rugby franchise into the stadium as its anchor tenant indicated that the Newlands Stadium, which was currently harbouring the rugby franchise, was approaching the end of its life cycle, leading to the opportunity to lure the local rugby franchise to the Cape Town Stadium. Additionally, the majority of the respondents $77.0 \%$ from Cape Town, $76.0 \%$ from Durban and $62.9 \%$ from Port Elizabeth) were of the view that the stadia could be used to promote the image of the country (V5), a view that was corroborated by a member of the Green Point Ratepayers' and Residents' Association in noting that: "It was very clear what they [FIFA] wanted from the very beginning, that they preferred Green Point, a location in front of Table Mountain, the surroundings and, as the results show, it is a marvellous place and makes the stadium a powerful tool for positioning the city as a preferred tourism and events destination."

The contemporary emphasis on the ability of sport mega-events to deliver legacies also raised the question of how the benefits could be leveraged and sustained post-event, especially in terms of the event-related infrastructure, such as the stadia (Rocha and Barbanti, 2015). Regarding the future potential of the stadia to promote the development of other activities to ensure their financial sustainability in the long-term, 76.2\% of the respondents from Cape Town, $70.6 \%$ of those from Durban and 63.6\% from Port Elizabeth were in concurrence (V6). With a combined $\mathrm{M}=3.759$ and $\mathrm{SD}=0.928$, the results again show that the perceptions were generally positive, with such a positive indication raising nuances as to why, in their current situations, the upkeep of the stadia is consistently reported to be burdensome for the taxpayer. Considering that most of the stadia were constructed as multi-purpose facilities, officials should consider the development of local events around the stadia, taking cognisance of the local realities, considering the meetings, incentives, conventions, and events (MICE) industry as a potential option for leverage. Interestingly, although current debates are rather contentious in relation to the present unsustainable nature of the stadia, most respondents $(60.9 \%$ of the respondents from Cape Town, 61.1\% from Durban and 35.8\% from Port Elizabeth) 
indicated that the use of public funds in support of the event was acceptable (V7), which one could assume is motivated by the intangible outcomes such as novelty, image enhancement and other socio-psychological effects that the stadia could have engendered. In a similar manner, $69.1 \%$ of the respondents from Cape Town, $68.1 \%$ from Durban and $61.4 \%$ in Port Elizabeth agreed with the assertion that the stadia could be used to leverage, and to attract, the hosting of other major and/or megaevents in the future, hinting at generally positive inclinations as to the future potential of the stadia in bidding for and hosting other events (V8).

Table 2. Infrastructure legacy impact dimensions linked to stadium construction (in \%)

\begin{tabular}{|c|c|c|c|c|c|c|c|c|c|c|c|c|c|c|c|c|}
\hline \multicolumn{17}{|c|}{ CPT $n=400 ;$ DUB $n=320 ;$ PE $n=400$} \\
\hline \multirow{2}{*}{ V\# } & \multirow{2}{*}{ Type of impact } & \multicolumn{3}{|c|}{ Strongly disagree } & \multicolumn{3}{|c|}{ Disagree } & \multicolumn{3}{|c|}{ Neutral } & \multicolumn{3}{|c|}{ Agree } & \multicolumn{3}{|c|}{ Strongly agree } \\
\hline & & СPT & DUB & $\mathrm{PE}$ & CPT & DUB & $\mathrm{PE}$ & СРT & DUB & $\mathrm{PE}$ & СРT & DUB & $\mathrm{PE}$ & СPT & DUB & $\mathrm{PE}$ \\
\hline v1 & $\begin{array}{l}\text { The stadium has } \\
\text { increased the number } \\
\text { of tourist visits to the } \\
\text { area. }\end{array}$ & 2.3 & 3.0 & 5.1 & 8.3 & 2.3 & 9.8 & 12.5 & 18.4 & 23.7 & 44.1 & 60.2 & 38.4 & 32.8 & 16.1 & 23.0 \\
\hline V2 & $\begin{array}{l}\text { The stadium has } \\
\text { increased positive } \\
\text { media coverage of the } \\
\text { area. }\end{array}$ & 2.0 & 0.0 & 4.8 & 7.5 & 3.6 & 11.4 & 15.0 & 19.8 & 23.7 & 54.6 & 63.4 & 38.4 & 20.8 & 13.2 & 21.7 \\
\hline V3 & $\begin{array}{l}\text { I feel proud that the } \\
\text { stadium was built in } \\
\text { my city/area. }\end{array}$ & 0.0 & 0.7 & 9.8 & 6.8 & 2.7 & 7.3 & 13.8 & 20.1 & 20.5 & 46.1 & 57.0 & 38.6 & 33.3 & 19.5 & 23.7 \\
\hline v4 & $\begin{array}{l}\text { I am confident that } \\
\text { the stadium can be } \\
\text { used to promote the } \\
\text { development of } \\
\text { football in the } \\
\text { area/country. }\end{array}$ & 0.5 & 0.0 & 9.8 & 4.8 & 2.0 & 9.8 & 15.0 & 27.9 & 17.4 & 58.1 & 51.8 & 39.9 & 21.6 & 18.4 & 23.0 \\
\hline V5 & $\begin{array}{l}\text { The stadium can be } \\
\text { used to promote/ } \\
\text { market the image of } \\
\text { the city/country. }\end{array}$ & 0.3 & 0.7 & 8.6 & 6.3 & 1.3 & 10.6 & 16.5 & 21.9 & 17.9 & 48.4 & 57.8 & 35.6 & 28.6 & 18.3 & 27.3 \\
\hline V6 & $\begin{array}{l}\text { The stadium can be } \\
\text { used to promote the } \\
\text { development of other } \\
\text { activities to ensure its } \\
\text { financial } \\
\text { sustainability in the } \\
\text { long-term. }\end{array}$ & 1.0 & 1.0 & 5.1 & 8.3 & 3.3 & 11.4 & 14.5 & 25.1 & 19.9 & 55.6 & 56.1 & 44.4 & 20.6 & 14.5 & 19.2 \\
\hline V7 & $\begin{array}{l}\text { I feel that the use of } \\
\text { public funds in } \\
\text { support of the } \\
\text { stadium was } \\
\text { acceptable. }\end{array}$ & 3.0 & 2.0 & 4.3 & 8.0 & 5.6 & 12.4 & 28.1 & 32.2 & 38.5 & 39.6 & 50.8 & 34.9 & 21.3 & 9.3 & 9.9 \\
\hline V8 & $\begin{array}{l}\text { The stadium can be } \\
\text { used for leverage to } \\
\text { attract the hosting of } \\
\text { other major events / } \\
\text { mega-events in the } \\
\text { future. }\end{array}$ & 2.5 & 2.3 & 6.6 & 9.5 & 3.3 & 12.4 & 18.8 & 26.3 & 19.7 & 51.1 & 50.0 & 40.7 & 18.0 & 18.1 & 20.7 \\
\hline V9 & $\begin{array}{l}\text { The cost of } \\
\text { maintenance for the } \\
\text { usage of the stadium } \\
\text { poses challenges for } \\
\text { local communities }\end{array}$ & 2.8 & 3.6 & 5.6 & 11.8 & 21.2 & 27.8 & 28.1 & 49.3 & 38.1 & 34.1 & 18.9 & 22.2 & 23.3 & 7.0 & 6.3 \\
\hline V10 & $\begin{array}{l}\text { The stadium is a } \\
\text { "White Elephant" } \\
\text { (waste of public } \\
\text { money) and should be } \\
\text { demolished }\end{array}$ & 19.5 & 12.5 & 17.7 & 28.8 & 38.0 & 43.4 & 25.8 & 29.6 & 19.7 & 18.3 & 16.2 & 11.6 & 5.3 & 3.7 & 7.6 \\
\hline
\end{tabular}

$\mathrm{CPT}=$ Cape Town, DUB= Durban, $\mathrm{PE}=$ Port Elizabeth 
The combined score across all three study areas was $\mathrm{M}=3.692$, indicating that the inclinations from the respondents as to the future potential of the stadia are generally positive. While these results might seem promising in terms of the outlook for the bidding and hosting of future events, the example of the 2022 Commonwealth Games being rescinded by South Africa is a worrying prospect for future mega-event bids and a compromising prospect on image enhancement that such infrastructure may portend when used for such events (Table 2). The country also lost the bid to host the 2023 Rugby World Cup (Ray, 2017), raising questions as to how soon in the current lifecycle of these stadia other major events could be leveraged. Anecdotal and scholarly work suggests that to ensure that future legacy objectives materialise, it is critical that legacy plans be conceptualised at an early stage in the lifecycle of the event planning, with clearly articulated expectations ensuring the goals are plainly identified and that the authority in charge of legacy is pinned down.

Table 3. Infrastructure legacy impact dimensions linked to stadium construction (in \%) Combined mean scores

\begin{tabular}{|c|c|c|c|c|}
\hline & $\begin{array}{c}\text { DU } \\
\text { B }\end{array}$ & $\begin{array}{c}\text { CP } \\
\mathbf{T}\end{array}$ & PE & $\begin{array}{l}\text { COMBIN } \\
\text { ED }\end{array}$ \\
\hline Type of infrastructure legacy impact dimension & $\mathbf{M}$ & $\mathbf{M}$ & $\mathbf{M}$ & $\mathbf{M}$ \\
\hline The stadium has increased tourists visits to the area & $\begin{array}{c}3.9 \\
7\end{array}$ & $\begin{array}{c}3.8 \\
4\end{array}$ & $\begin{array}{c}3.6 \\
4\end{array}$ & 3.819 \\
\hline The stadium has increased positive media coverage of the area & $\begin{array}{c}3.8 \\
5\end{array}$ & $\begin{array}{c}3.8 \\
6\end{array}$ & $\begin{array}{c}3.6 \\
1\end{array}$ & 3.772 \\
\hline I feel proud that the stadium was built in my city/area & $\begin{array}{c}4.0 \\
6\end{array}$ & $\begin{array}{c}3.9 \\
2\end{array}$ & $\begin{array}{c}3.5 \\
9\end{array}$ & 3.857 \\
\hline $\begin{array}{l}\text { I am confident the stadium can be used to promote the development of football in the } \\
\text { area/country }\end{array}$ & $\begin{array}{c}3.9 \\
5\end{array}$ & $\begin{array}{c}3.8 \\
7\end{array}$ & $\begin{array}{c}3.5 \\
6\end{array}$ & 3.795 \\
\hline The stadium can be used to promote/ market the image of the city/country & $\begin{array}{c}3.9 \\
9\end{array}$ & $\begin{array}{c}3.9 \\
2\end{array}$ & $\begin{array}{c}3.6 \\
2\end{array}$ & 3.843 \\
\hline $\begin{array}{l}\text { The stadium can be used to promote the development of other activities to ensure its financial } \\
\text { sustainability in the long-term }\end{array}$ & $\begin{array}{c}3.8 \\
6\end{array}$ & $\begin{array}{c}3.8 \\
0\end{array}$ & $\begin{array}{c}3.6 \\
1\end{array}$ & 3.759 \\
\hline I feel that the use of public funds in support of the event was acceptable & $\begin{array}{c}3.6 \\
8\end{array}$ & $\begin{array}{c}3.6 \\
0\end{array}$ & $\begin{array}{c}3.3 \\
4\end{array}$ & 3.539 \\
\hline $\begin{array}{l}\text { The stadium can be used to leverage to attract the hosting of other major/mega-events in the } \\
\text { future }\end{array}$ & $\begin{array}{c}3.7 \\
3\end{array}$ & $\begin{array}{c}3.7 \\
8\end{array}$ & $\begin{array}{c}3.5 \\
7\end{array}$ & 3.692 \\
\hline I have become a participant of sport activities due to the construction of the stadium & $\begin{array}{c}3.3 \\
3\end{array}$ & $\begin{array}{c}3.0 \\
4\end{array}$ & $\begin{array}{c}3.1 \\
2\end{array}$ & 3.162 \\
\hline I have become a spectator of sport activities due to the construction of the stadium & $\begin{array}{c}3.4 \\
7\end{array}$ & $\begin{array}{c}3.0 \\
9\end{array}$ & $\begin{array}{c}3.1 \\
3\end{array}$ & 3.232 \\
\hline The cost of maintenance for the usage of the stadium poses challenges for local communities & $\begin{array}{c}3.6 \\
3\end{array}$ & $\begin{array}{c}3.0 \\
4\end{array}$ & $\begin{array}{c}2.9 \\
6\end{array}$ & 3.212 \\
\hline The stadium is a "White Elephant" (waste of public money) and should be demolished & $\begin{array}{c}2.6 \\
5\end{array}$ & $\begin{array}{c}2.6 \\
1\end{array}$ & $\begin{array}{c}2.4 \\
8\end{array}$ & 2.580 \\
\hline
\end{tabular}

$\mathrm{CPT}=$ Cape Town, DUB= Durban, $\mathrm{PE}=$ Port Elizabeth $\mathrm{M}=$ Mean.

Mounting evidence, especially in the developing context, presents challenges to the ability of mega-events in producing sustainably positive stadium 
infrastructure legacies (Bama and Tichaawa, 2020; Boykoff, 2014; Cottle, 2010; Molloy and Chetty, 2015). In this vein, a significant portion of Cape Town respondents (57.4\%) indicated that the maintenance costs of the stadium were exorbitant, while $25.9 \%$ and $28.5 \%$ gave similar responses in Durban and Port Elizabeth, respectively (V9). The results seemed to lean towards the proposition in certain quarters that mega-events are agents of homogenisation, with policies that lead to the production of white elephants (Cottle, 2010; Molloy and Chetty, 2015). Because of the diversity of debates as to whether mega-events are agents of homogenisation, propagating policy models and white elephants across the globe, scholars, event organisers, and the public alike need to be careful not to generalise from the impacts of one event to others. As such the views of respondents were sought on whether the stadia constituted white elephants and should be demolished. Although resolute that the costs of keeping the structures operational were in some cases excessive, the responses, in this case, were varied. In a twist of responses, most of the respondents (48.3\% in Cape Town, 50.5\% from Durban and 61.1\% from Port Elizabeth) disagreed with any suggestions of demolition (V10). As such while the rejection of the demolition option might also have highlighted the affinity and attachment to, and the sense of pride in the stadia, as held by the residents, in order to maximise positive sustainable legacies, support from all stakeholder sectors is required.

\section{Conclusions}

The focal thrust of this study was the urban infrastructure legacy impacts of mega-event stadia in the Global South with a specific consideration of South Africa's 2010 stadia. The study presented an initiation point for the analysis of the legacy constructs of mega-events infrastructure development and their sustainability within developing economies, specifically with regards to South Africa's hosting of the 2010 FIFA World Cup, and, revealed a dichotomy of views among stakeholders in relation to the legacy impacts of mega-event stadia with both benefits and costs being highlighted. While the construction of the stadia had promoted the urban renewal strategy of the respective locations, one of the key outcomes was that poor stakeholder engagement had hampered community support for the stadia, and the results in certain cases, were quite contentious. Due to calls from experts for legacy impacts of mega-events to be tested over time, and obtain further insights of the post-2010 stadium infrastructure legacy impacts, a systematic analysis of residents' and other key stakeholders' perceptions should be conducted in a longitudinal endeavour, and should focus on the sustainability of the urban planning contradictions affecting the infrastructural legacy outcomes. Another contention for further review would be in relation to the novelty considerations, the increase in comfort, the improved view, and the enhanced atmosphere of the stadia with the associated benefits being community pride and other healthrelated benefits, among others.

Furthermore, a key issue that was not considered as part of the scope of this research entailed examining the net economic gain/loss to the various host communities, as a result of the construction of the stadia, and it is therefore 
suggested that this form the basis of further enquiry into the subject matter. Evidently, due to the mutable timelines that were in place for the construction of the stadia, and accompanied by the contentious debates that surrounded the issue, the host LOC's became more engulfed with planning to try to meet the FIFA datelines and therefore paid less attention to the infrastructure legacy planning thereby ignoring future considerations as to what becomes of the stadia post-event. An outcome of the present study was the nuanced view that the event owners exercised undue influence in selecting the locations of such event infrastructure as the stadia. It is recommended that the event owners such as FIFA, in making suggestions, engage with the government authorities in the host communities, and take into account the wider ramifications of the post-event realities that the investments are bound to attract.

Additionally the study found that there was a concerted paucity in consultation between key stakeholder groups. It is, therefore, imperative to set up a framework to guide how the communication between the different stakeholders groups involved in, and impacted on by, such events should be managed more braodly. A final recommendation is for the incorporation of the voices of all stakeholder groups in examining the long-term stadium infrastructure legacy impacts of mega-events, specifically in relation to economies in transition.

\section{Acknowledgements}

This paper forms part of a doctoral research submitted to School of Tourism and Hospitality at the University of Johannesburg. The University of Johannesburg is thanked for funding the current research.

\section{References}

Agha, M. (2013). The economic impact of stadia and teams: The case of minor league baseball. Journal of Sport Economics, 14(1), 227-252.

Allen, D., Knott, B. \& Swart, K. (2013). Africa's tournament: The branding legacy of the 2010 FIFA World Cup. The International Journal of the History of Sport, 30(16), 1994-2006.

Alm, J., Tofft-Jørgensen, L., Brandt, H., Bang, S., Pedersen, A., Candy, J. \& Flickr, A. S. (2012). World Stadium Index: Stadiums built for major sporting events-bright future or future burden? (web-source: http://www.playthegame.org/fileadmin/documents/World_Stadium_Index_Final.pdf (Accessed on 2017.08.11).

Almeida, B. S. D., Júnior, M. W. \& Pike, E. (2014). The 2016 Olympic and Paralympic Games and Brazil's soft power. Contemporary Social Science, 9(2), 271-283.

Bama, H. K. N. (2018). Sustainable mega-event infrastructure development in developing economies: a case study of the infrastructural legacy impacts of selected 2010 FIFA World Cup stadia in South Africa. Unpublished PhD thesis. University of Johannesburg, Johannesburg.

Bama, H. K. N. \& Tichaawa, T. M. (2020). Mega-event and stadium legacies in the Global South: the case of South Africa. In New Directions in South African Tourism Geographies, 129-145. Springer, Cham.

Bama, H. K. N., \& Tichaawa, T. M. (2016). Mega-event infrastructure development and sustainability contestations in the developing context: The 2010 FIFA World Cup in South Africa. African Journal of Hospitality, Tourism and Leisure, 5(3), 1-18.

Bama, H. K. N., \& Tichaawa, T. M. (2015). Major sporting events and responsible tourism: Analysis of the 2013 Africa Cup of Nations (AFCON) tournament in Port Elizabeth, South Africa. African Journal for Physical, Health Education, Recreation and Dance, 21, 205-219. 
Bassa, Z. \& Jaggernath, J. (2010). Living close to 2010 stadiums: Residents' perceptions of the 2010 FIFA World Cup and stadium development in Durban, South Africa. Alternation, 17(2), 121-145.

Black, D. (2007). The symbolic politics of sport mega-events: 2010 in comparative perspective. Politikon, 34(3), 261-276.

Blomgren, J. \& Valkonen, T. (2007). Characteristics of urban regions and all-cause mortality in workingage population: Effects of social environment and interactions with individual unemployment. Demographic Research, 17(5), 109-134.

Bob, U. \& Kassens-Noor, E. (2012). An indicator framework to assess the legacy impacts of the 2010 FIFA World Cup. African Journal for Physical, Health Education, Recreation and Dance (AJPHERD), Supplement 1, 12-21.

Bocarro, J., Byers, T. \& Carter, C. (2018). Legacy of sporting and non-sporting mega event research. Legacies and mega-events: Facts or fairy tales, 7-24.

Boykoff, J. (2014). Celebration capitalism and the Olympic Games. London: Routledge.

Brittain, I., Bocarro, J., Byers, T. \& Swart, K. (eds.). (2018). Legacies and Mega Events: Fact or Fairy Tales?. London: Routledge.

Byers, T., Hayday, E.J. \& Pappous, A. (2019). A new conceptualization of mega sports event legacy delivery: Wicked problems and critical realist solution. Sport Management Review, doi:10.1016/j.smr.2019.04.001.

Cashman, R. \& Horne, J. (2013). Legacy management. In Managing the Olympics. Edited by Frawley, S. \& Adair, D. Houndmills: Palgrave Macmillan.

Cezne, E. (2014). Sports mega-events and development: A critical analysis of Brazil's hosting of the 2014 FIFA World Cup and 2016 Summer Olympic Games. Unpublished Bachelor's thesis. Norwegian University of Life Sciences, As.

Chappelet, J. \& Junod, T. (2006). A tale of 3 Olympic cities: What can Turin learn from the Olympic legacy of other Alpine cities? In Major sport events as opportunity for development (pp. 83-90). Edited by Torres, D. Valencia.

Chen, Y., Qu, L. \& Spaans, M. (2013). Framing the long-term impact of mega-event strategy on the development of the Olympic host cities. Planning Practice \& Research, 28(3), 340-359.

Clark, J., Kearns, A. \& Cleland, C. (2016). Spatial scale, time and process in mega-events: The complexity of host community perspectives on neighbourhood change. Cities, 53, 87-97.

Coates, D. (2007). The tax benefits of hosting the Super Bowl and the MLB All-Star Game: The Houston experience. International Journal of Sport Finance, 1(4), 239-252.

Cornelissen, S. (2007). Crafting legacies: The changing political economy of global sport and the 2010 FIFA World Cup. Politikon, 34(3), 241-259.

Cornelissen, S., Bob, U. \& Swart, K. (2011). Towards redefining the concept of legacy in relation to sport mega-events: Insights from the 2010 FIFA World Cup. Development Southern Africa, 28(3), 307-318.

Cottle, E. (2010). A preliminary evaluation of the impact of the 2010 FIFA World Cup in South Africa. (web-source: http://www.Irs.org.za/docs/A\%20Preliminary\%20Evaluation\%20of\%20the $\% 20$ Impact $\% 20$ of $\% 20$ the $\% 2$ 02010\%20World\%20Cup\%20by\%20EddieCottle.pdf (Accessed on 2011.06.18).

Desai, A. \& Vahed, G. (2010). World Cup 2010: Africa's turn or the turn on Africa? Soccer and Society, 11(1-2), 154-167.

Douglas, B. (2015). World Cup leaves Brazil with bus depots and empty stadiums. (web-source: http://www.bbc.com/sport/0/football/32073525, (Accessed at: 2019.06.18).

Erten, S. \& Özfiliz, S. (2006). Stadium construction and sustainability: The review of mega-event stadiums (1990-2012). 1st International CIB Endorsed METU Postgraduate Conference, Ankara, Turkey (525-541). (web-source: http://www.irbnet.de/daten/iconda/06059012396.pdf, (Accessed on 2010.04.11).

Ferrari, S. \& Guala, C. (2017). Mega-events and their legacy: Image and tourism in Genoa, Turnin and Milan. Leisure Studies, 36(1), 199-137.

Gaffney, C. (2013). Between discourse and reality: The un-sustainability of mega-event planning. Sustainability, 5(9), 3926-3940.

Gaffney, C. (2015). The urban impacts of the 2014 World Cup in Brazil. In Mega-events and globalisation: Capital and spectacle in a changing world order (pp. 167-185). Edited by Gruneau, R. \& Horne, J. London: Routledge. 
Giampiccoli, A., Lee, S. S. \& Nauright, J. (2015). Destination South Africa: Comparing global sports megaevents and recurring localised sports events in South Africa for tourism and economic development. Current Issues in Tourism, 18(3), 229-248.

Girginov, V. (2011). Governance of London 2012 Olympic Games legacy. International Review for the Sociology of Sport, 47(5), 543-558.

Grix, J. \& Brannagan, P.M. (2017). Of mechanisms and myths: Conceptualizing state's 'soft power' strategies through sports mega-events. Diplomacy and Statecraft, 27(2), 251-272.

Gold, J. R. \& Gold, M. M. (Eds.). (2016). Olympic cities: City agendas, planning, and the world's games, 1896-2020 (3rd ed.). London: Routledge.

Groothuis, P. A. \& Rotthoff, K. W. (2014). Surveying the literature and the people: The economic impact of sports teams and civic pride. Social Science Research Network, 14(5), 1-22.

Gunter, A. (2014). Mega events as a pretext for infrastructural development: The case of the All African Games Athletes Village, Alexandra, Johannesburg. Bulletin of Geography. Socio-economic Series, 23(23), 39-52.

Hemmonsbey, J. \& Tichaawa, T. M. (2018). The effects of major sport event leveraging for tourism and destination branding: The case of South Africa as an emerging destination. GeoJournal of Tourism and Geosites, 21(1), 213-282.

Hemmonsbey, H. \& Tichaawa, T. M. (2019). Using non-mega events for destination branding: A stakeholder perspective. GeoJournal of Tourism and Geosites, 24(1), 252-266.

Hlabane, B. (2012). The political, economic and social impact of hosting mega-sports events: The 2010 South Africa World Cup in comparative perspective, unpublished PhD thesis, Ritsumeikan Asia Pacific University, Oita, Japan.

Humphrey, L. \& Fraser, G. (2016). 2010 FIFA World Cup stadium investment: Does the post event usage justify the expenditure? African Review of Economics and Finance, 8(2), 3-22.

Ilieș, A., Dehoorne, O., Wendt, J. \& Kozma, G. (2014). For geography and sport, sport geography or geography of sport, GeoSport for Society, 1(1-2), 7-18.

Jaworek, M., Karaszewski, W., Kuczmarska, M. \& Kuzel, M. (2020). Investment expenditure on sport infrastructure in Poland: diagnosis, general trends, and possible prospects. Journal of Physical Education and Sport, 20(2), 1106-1114.

Johnson, R. B. \& Onwuegbuzie, A. J. (2004). Mixed methods research: A research paradigm whose time has come. Educational researcher, 33(7), 14-26.

Jory, S. \& Boojihawon, D. (2011). The economic implications of the FIFA 2010 World Cup in South Africa. African Journal of Business and Economic Research, 6(1), 7-21.

Kassens-Noor, E., Vertalka, J. \& Wilson, M. (2019). Good games, bad host? Using big data to measure public attention and imagery of the Olympic Games, Cities, 90(2), 229-236,

Kassens-Noor, E. \& Kayal, P. (2016). India's new globalization strategy and its consequences for urban development: The impact of the 2010 Commonwealth Games on Delhi's transportation system. International Planning Studies, 21(1), 34-49.

Kiernan, P. (2014). World Cup hit Brazil's economy hard. Wall Street Journal. (web-source: https://blogs.wsj.com/moneybeat/2014/07/18/world-cup-hit-brazils-economy/ (Accessed on 2019.06.18).

Kim, H., Choe, Y., Kim, D. \& Kim, J. (2019). For Sustainable Benefits and Legacies of Mega-Events: A Case Study of the 2018 PyeongChang Winter Olympics from the Perspective of the Volunteer CoCreators, Sustainability, 11, 2473.

Koch, N. \& Valiyev, A. (2016). Urban boosterism in closed contexts: Spectacular urbanization and second-tier mega events in three Caspian capitals. Eurasian Geography and Economics, 56(5), 575-598.

Koehler, P. (2012). Why do some stadium redevelopment projects succeed where others fail? An analysis using macro-level trends in stadium building. Colgate University, Summer 2012. (web-source: https://www.colgate.edu/docs/default-source/default-document-library/koehlerpdf.pdf?sfvrsn=0, (Accessed on 2015.06.18).

Kunzmann, K. R. (2016). Crisis and planning? A commentary. European Planning Studies, 24(7), 1313-318.

Leopkey, B. \& Parent, M. M. (2012). Olympic Games legacy: From general benefits to sustainable longterm legacy. International Journal of the History of Sport, 29(6), 924-943. 
Lin, G. C. S. \& Xu, Z. (2019). Remaking China's urban space of the spectacle: Mega-events, temporary growth, and uneven spatial transformation in Shanghai. Geoforum, 102, 126-136.

Maharaj, B. (2011). 2010 FIFA World Cup: (South) Africa's time has come? South African Geographical Journal, 93(1), 49-62.

Mills, B. M. \& Rosentraub, M. S. (2013). Hosting mega-events: A guide to the evaluation of development effects in integrated metropolitan regions. Tourism Management, 34, 238-246.

Molloy, E. \& Chetty, T. (2015). The rocky road to legacy: Lessons from the 2010 FIFA World Cup South Africa stadium program. Project Management Journal, 46(3), 88-107.

Montgomery, M. R. (2008). The urban transformation of the developing world. Science, 319(5864), 761-764.

Moshoeshoe, M. (2014). Residents' perceptions of the 2010 FIFA World CupTM in Port Elizabeth: A pre- and post-event comparison. Unpublished Master's dissertation. Cape Peninsula University of Technology, Cape Town.

Müller, M. (2017). How mega-events capture their hosts: event seizure and the World Cup 2018 in Russia. Urban Geography, 38(8), 1113-1132.

Müller, M. \& Gaffney, C. (2018). Comparing the Urban Impacts of the FIFA World Cup and Olympic Games From 2010 to 2016. Journal of Sport and Social Issues, 42(4), 247-269.

Patel, K. (2016). Brazilian perspectives on the 2014 FIFA World Cup and the 2016 Olympic Games. University of Vermont Honors College senior theses, Paper 113.

Philips, C. \& Barnes, M. (2015). Whose legacy is it, anyways? A tale of conflicting agendas in the building of the Hamilton Pan Am Soccer Stadium. Annals of Leisure Research, 18(4), 549-568.

Preuss, H. (2007). The conceptualisation and measurement of mega sport event legacies. Journal of Sport and Tourism, 12(3-4), 207-227.

Preuss, H. (2011). A method for calculating the crowding-out effect in sport mega-event impact studies: The 2010 FIFA World Cup. Development Southern Africa, 28(3), 367-385.

Preuss, H. (2013). The contribution of the FIFA World Cup and the Olympic Games to green economy. Sustainability, 5(8), 3581-3600.

Preuss, H. (2015). A framework for identifying the legacies of a mega sport event. Leisure studies, 34(6), 643-664.

Ray, C. (2017). South Africa loses bid to host 2023 Rugby World Cup. (web-source: https://www.timeslive.co.za/sport/rugby/2017-11-15-south-africa-lose-bid-to-host-2023-rugbyworld-cup/ (Accessed on 2019.06.18).

Ren, X. (2017). Aspirational urbanism from Beijing to Rio de Janeiro: Olympic cities in the Global South and contradictions. Urban Affairs, 39(7), 894-908.

Robbins, G. (2012). Major international events and the working poor: Selected lessons for social actors stemming from the 2010 soccer World Cup in South Africa. WIEGO Technical Brief. Urban Policies, 5, 1-29.

Rocha, C. M. \& Barbanti, V. J. (2015). Support for the 2014 FIFA World Cup and the 2016 Olympic Games. Journal of Physical Education and Sports Management, 2(2), 66-87.

Rosentraub, M. S. (2010). Major league winners: Using sports and cultural centers as tools for economic development. Boca Raton, FL: CRC Press.

Smith, A. \& Fox, T. (2007). From 'event-led' to 'event-themed' regeneration: The 2002 Commonwealth Games legacy programme. Urban Studies, 44(5/6), 1125-1143.

Steinbrink, M., Haferburg, C. \& Ley, A. (2011). Festivalisation and urban renewal in the Global South: Socio-spatial consequences of the 2010 FIFA World Cup. South African Geographies, 93(1), 15-28.

Stewart, A. \& Rayner, S. (2016). Planning mega-event legacies: uncomfortable knowledge for host cities. Planning perspectives, 31(2), 157-179.

Sturgess, D. \& Brady, C. (2006). Hosting the FIFA World Cup economic boon or winner's curse? Journal of Current Economic Analysis and Policy, 7(4), 145-164.

Swart, K. \& Bob, U. (2012). Mega sport event legacies and the 2010 FIFA World Cup. African Journal for Physical, Health Education, Recreation and Dance, Supplement 1, 1-11.

Swart, K. \& Bob, U. (2009). Venue selection and the 2010 World Cup: A case study of Cape Town. In Development and dreams: The urban legacy of the 2010 Football World Cup. Edited by Pillay, B. Tomlinson, R. \& Bass, O. Cape Town: HSRC Press, 114-130. 
Thomson, A., Cuskelly, G., Toohey, K., Kennelly, M., Burton, P. \& Fredline, L. (2018). Sport event legacy: A systematic quantitative review of literature. Sport Management Review, 1-27.

Tichaawa, T. M. \& Bama, H. K. N. (2012). Green Point residents' perceptions of the 2010 FIFA World Cup: A post-event analysis. In: African Journal for Physical, Health Education, Recreation and Dance (AJPHERD), 18(2), 22-32.

Tichaawa, T. M., Bama, H. K. N. \& Swart, K. (2015). Community perceptions of the socio-economic legacies of the 2010 FIFA World Cup in Nelson Mandela Bay, Port Elizabeth: A four-year post-event analysis. African Journal for Physical, Health Education, Recreation and Dance, 21(4:2), 1383-1395.

Tomlinson, A. (2014). Olympic legacies: Recurrent rhetoric and harsh realities. Contemporary Social Science, 9(2), 137-158.

Wood, A. (2017). Advancing development projects through mega-events: The 2010 football World Cup and bus rapid transit in South Africa. Urban Geography, 1-7.

Zimbalist, A. (Ed.). (2017). Rio 2016: Olympic Myths, Hard Realities. Washington, D.C.: Brookings Institution Press. 